\title{
SWEARING USED IN RICHARD WRIGHT'S BLACK BOY
}

\author{
Giyatmi \\ Universitas Veteran Bangun Nusantara Sukoharjo \\ giyatmi85jimmy@gmail.com \\ Ratih Wljayava \\ Universitas Veteran Bangun Nusantara Sukoharjo \\ ratihwijayava@gmail.com \\ Nunun Tri Widarwati \\ Universitas Veteran Bangun Nusantara Sukoharjo \\ nununtriwidarwati@gmail.com
}

DOI: http://dx.doi.org/10.18326/rgt.v10i1.62-82

\section{ENGLISH ABSTRACT}

This research aims at finding the types of swearing expressions and linguistic forms of English swearing used in Richard Wright's Black Boy. This is a descriptive qualitative research since it describes the phenomena of swearing used in the novel. The data of the research are all the conversations or sentences used swearing in the novel written by Richard Wright namely Black Boy as the main data source. The method of collecting data in this research is observation and teknik lanjut catat. After all the data had been collected then they are coded using the coding system such as data number/title of novel/chapter/page/data. There is no data reduction since all the data are analyzed in this research. This research used theory triangulation. Kind of swearing expressions found in this novel dealing with God and religion terms, name of animals and plants, part of body, racial terms, stupidity terms, name of occupation, sexual terms, family terms. The linguistic forms of English swearing used in this novel are word, phrase, and clause. The swearing in the form of words consists of (1) noun referring to place, person, occupation, animal, and idea (2) verb and (3) adjective. Phrase consists of (1) noun phrase with swearing functioning as headword, modifier, and both headword and modifier, (2) adjective phrase with swearing functioning as modifier. Swearing expression is also found in the form of sentence.

Keywords: taboo, swearing, and linguistic form.

\section{INDONESIAN ABSTRACT}

Penelitian ini bertujuan untuk menemukan jenis makian serta satuan bahasa dari makin berbahasa Inggris yang digunakan dalam novel Richard Wright yang berjudul Black Boy. Penelitian ini berjenis deskriptif kualitatif karena penelitian ini berusaha menjelaskan 
fenomena makian yang terdapat pada novel Black Boy karya Richard Wright. Data pada penelitian ini adalah semua kata, frasa, klausa, kalimat yang mengandung kata makian dalam percakapan di novel Black Boy karya Richard Wright yang merupakan sumber data primer dalam penelitian ini. Metode pengumpulan data dalam penelitian ini adalah observasi dan teknik lanjut catat. Setelah semua data terkumpul maka data diberi kode dengan system kode yang sudah ditentukan yaitu nomor data/judul novel/BAB dalam novel/halaman novel/data. Semua data yang ditemukan dalam penelitian ini dianalisis, sehingga tidak ada reduksi data. Penelitian ini menggunakan trianggulasi teori. Jenis makian yang ditemukan dalam novel ini terkait dengan nama tuhan serta istilah keagamaan, nama hewan dan tumbuhan, nama bagian tubuh, istilah rasial, istilah yang bersinonim dengan hal yang menunjukkan kebodohan, nama pekerjaan, istilah aktivitas seksual, dan istilah yang terkait dengan keluarga. Sementara itu dari satuan lingual, makian dapat berbentuk kata yang terdiri dari (1) kata benda yang merujuk pada tempat, orang, pekerjaan, binatang serta idea (2) kata kerja (3) kata sifat. Frase yang digunakan dalam makian pada novel ini meliputi (1) frase kata benda dengan posisi kata makian sebagai kata inti (head word), penjelas (modifier), serta berfungsi sebagai keduanya baik kata inti (head word) dan penjelas (modifier), (2) frase kata sifat dengan kata makian sebagai penjelasan (modifier). Ekspresi makian juga ditemukan dalam bentuk kalimat.

Kata kunci: tabu, makian dan satuan lingual.

\section{INTRODUCTION}

Richard Wright was one of famous American authors. He wrote some novels, short stories, poems, and non-fictions. Many of his works concern with racial theme. One of his novels is Black Boy: A Record of Childhood and Youth. It is considered to be a semi autobiography, because the novel tells about his early life then moved to Chicago. He started his writing career and became involved with Political Party in that town. This novel was written in 1945 and became best seller.

Having read this novel, the writer found interesting language phenomenon, i.e. the use of swearing. Richard Wright used many swearing expressions in the novel. It is easy to find swearing expression such as Damn, Hell, Goddamn, Sonofabitch in this novel. Swearing is an offensive word, usually as an expression of anger. Swearing is considered to be impolite and taboo so that many people avoid it.

Swearing is often associated with negative emotion such as anger, disappointment. Actually swearing can be related to the positive emotion. Swearing can be used to express relief, happiness or even admiration. It depends on the context. Swearing as one of language expressions is influenced by the context surrounded it. 
Broadly speaking, context is the environment where the utterance or expression happens. Mey $(1993 ; 38)$ defines context as the surroundings, in the widest sense, that the participants in the communication process to interact, and that make the linguistics expression of their interaction intelligible. Context can bring swearing expression to be positive or negative emotion. For example the word damn can mean negative when it is spoken by a who gets angry after knowing that his girlfriend had an affair with his friend. On the other hand, damn can mean positive when it is used by the speaker who finally accidentally meets his old friend with whom he have not seen yet since high school graduation. So, to sum up, context plays an important part in determining meaning of an utterance or expression.

Swearing is common in languages but not universal. There are some communities such as Indian America, Malay, and most of Polynesian languages do not swear (Montagu in Geoffrey, 1998; 3). Swearing is influenced by culture and belief of the society using the swearing. In one society maybe a certain word is not considered as swearing but in another society maybe that certain word is swearing. For example is jangkrik (cricket) which is considered as swearing in East Java, Indonesia but not in Central Java, Indonesia. Jangkrik (cricket) is a name of animal. There are many animals used as swearing such as dog, bitch and pig. Besides, there are still many sources used as swearing expression such as part of body for instance eyes and lips (mata dan bibir in Javanese society), ass (in English language). Swearing can be also got from the bad behavior of someone such as silly, stupid (bodoh in Indonesia).

The writer is interested in the English swearing found in Richard Wright's Black Boy so that the writer had a research on it. The research focused on the type of swearing and linguistic forms used on swearing found in Richard Wright's Black Boy.

\section{Previous Study}

Swearwords seem to be very interesting to study hence there are many researches dealing with swearwords. The researchers presented some previous researches dealing with swearword to complete the researchers' study. Ririn Febrima and Rusdi Noor Rose in Swearwords Found in Chat Room Yahoo Messenger (2012) focus their study on kinds of swearwords used by the people in Indian Chat Room Yahoo Messenger and the functions of swearwords used by the people in Indian Chat Room Yahoo Messenger. This research shows 
that there are 6 kinds of swearwords used in Indian Chat Room Yahoo Messenger such as the swearwords related to (1) supernatural or internal power of Gods, angels and devils (2) swearwords related to the future life (3) swearwords related to the names of ancestors and heroes (4) oaths by natural objects, forces, and phenomena (5) vulgar or obscene words (6) oaths by animals, plants, and their products. Meanwhile, the swearwords used in this chat room functions as anger, joke, surprise, unbelievable, promise, convince, and disappointment.

Elisa Nuraini, A comparative Study of English and Indonesian Swear Words on English and Indonesian Movie (2009) emphasizes on the linguistics form types of the swearwords employed by the characters in Indonesian and English Movies and the meaning of the swear words found in Indonesian and English Movie. The result of the study shows that the type of swearwords employed by the characters in Indonesian and English Movies are single word, compound word, noun phrase, verb phrase, and adjective phrase. Besides, the research shows that the meanings of swearword are to express anger, to intensify, to express annoyance, to insult, to disprove one's statement, to express surprise and to mock.

The two previous studies mentioned used chat room and movies to get the data, while this research uses novel, The Black Boy by Richard Wright to get the data. In addition this research focuses on kinds of swearing and linguistic forms found in Richard Wright's Black Boy.

\section{Taboo}

Taboo is closely related to swearing so that's why it is necessary to discuss it. Taboo comes from Tongan language, an Austronesia language of the Polynesian branch spoken in Tonga (in Pacific Ocean). Taboo was firstly introduced into English by Captain Cook in 1777. Broadly speaking, taboo means forbidden to be said, to be used because of its contradiction to the value in the society and culture.

Winick (in Laksana, 2009; 17) defines taboo is a prohibition, which, if violated, leads to an automatic penalty inflicted by magic and religion. Frazer in (Laksana, 2009; 25) classifies taboo into taboo of action, taboo of people, taboo of property, and taboo of words. Furthermore, Frazer classifies taboo words into taboo of parents' name, taboo of family, taboo of dead people, taboo of sacred person or animal, taboo of God's name, and taboo of certain words. 
In addition (Wijana; 242) mentions that taboo can appear in three ways such as taboo of fear, taboo of delicacy, and taboo of property. Taboo of fear refers to the forbidden of mentioning God's name, spirit and animal. The example of this taboo is taboo word for animal such as bear which people prefer calling it honey eater because of its totem power (Geoffrey,1998; 8). When people avoid of naming something that is not worth saying such as name of disease and death, it is the implementation of taboo of delicacy. Geoffrey $(1998 ; 10)$ states that virtually all societies have, for instance taboo against direct reference to death: invariably preferred is some euphemism concerning journey to unknown destination, such as pass on, pass away or more uplifting variant of Salvation Army, promoted to the glory. Taboo of property has something to do with sexual, parts of body as well as their function.

\section{Swearing}

Swearing is usually known as a word or phrase considered unacceptable in polite language, and used to express strong feeling such as anger, or to give offense. Montagu (in Laksana, 2001; 26) states that swearing is the act of verbally expressing the feeling aggressiveness that follows upon frustration in words possessing strong emotional association. Another definition is given by Crystal $(1992 ; 61)$, swearing is the complex and sophisticated expression that may be found in religion, legal and formal context. At the other, there are many daily examples of taboo speech, usually profanities or obscenities that express such emotion as hatred, antagonism, frustration and surprises. To sum up, it can be said that swearing is a kind of verbal expression used to express strong emotion association such as anger, hatred, frustration, and surprises.

Crystal mentions the sources of swearing such as things that have something to do with sexual activity, secretion, and supernatural (1992; 61). Still from Crystal, swearing is classified into (1) parts of body and their functions that are considered taboo and impolite in the society such as ball and four letter words, (2) name of God, evil, holy place, hereafter life, saint people such as God, Dear Lord, Heaven, Hell, by heard of the Prophet.

Ajib Rosidi in Kata Makian in http://sainstory.wordpress.com/2011/12/01/kata-katamakian/, classifies swearing into (1) those which have something to do with religion and belief (2) those which have something to do with sex (3) those which have something to do 
with parts of body (4) those which have something to do with function of human body (5) those which have something to do with synonymy of stupidity (6) names of animal.

Another article from Choiron in dalam Manfaat Memaki (Bukan Kamus Makian) pada http://bahasa.kompasiana.com/2011/03/26/manfaat-memaki-bukan-kamus-makian/ mentions that most of society share similarity on theme that deals with swearing such as (1) human body and its defects (2) weakness of bad attitude of person (3) human organ dealing with secretion (4) sexual activity (5) animal which are considered low and small (6) insect such as jangkrik (7) fruit such as jambu (8) bad name of family.

In Budiawanto (2006; 5), English swearing develops in three stages. The first is in $16^{\text {th }}$ century. In this stage, most swearing refers to euphemism for God's name such as God blind me, bloody by my lady. The next stage is in the $18^{\text {th }}$ century. Swearing dealing with God's name euphemism was decreasing in this stage. England started to clean their language from such kind of swearing. Most of swearing refers to the parts of body and their function such as cock, and cunt, the genital organs for male and female. The last stage is on the $20^{\text {th }}$ century, in which swearing has something to do with racial issues and sexuality, such as nigger, which means people having black skin.

\section{Linguistic Forms}

Language consists of two elements i.e. form and meaning. Linguistic form includes phonological units such as phonemes and syllables. On the other hand, grammatical units such as morphemes, phrases, clauses, sentences, and discourses (Ramlan, 2005; 21)

\section{a. Word}

Word is the smallest of linguistic units which can occur on its own speech or writing (Richard, 1985; 311) Similar definition of word from Crystal saying that word is the smallest unit of linguistic that can stand independently. In the written form, word is separated by spaces and in the spoken form; it is recognized by pause (Crystal, 1992; $\mathrm{xxx})$

To sum up, the two definitions are viewed word from the orthographical point of view. Word is classified into content word and function word. Content word refers to object, events, and abstract concept. Content words consist of noun, verb, adjective, and adverb. On the other hand, function words are those kinds of words that are often best 
defined by its function (Aronoff and Fudeman, 2005; 40). Articles, conjunctions, pronouns, prepositions are the examples of function words.

\section{b. Phrase}

Richard mentions that phrase is a group of words which form grammatical units. A phrase does not contain a finite verb and does not have a subject-predicative structure $(1985 ; 39)$. Based on the definition there is no finite verb and subject-predication on a phrase, however a phrase consists elements name Headword and modifier.

Based on its headword, phrase can be classified into noun phrase, verb phrase, adjective phrase, and adverb phrase.

\section{c. Clause and Sentence}

Clause is a group of words which form a grammatical unit and which contains a subject and finite verb. A clause forms a sentence of part of a sentence and often functions as a noun, an adjective, or an adverb (Richard, 1985; 39)

Clause has already had a subject and predicate but clause cannot stand independently because the meaning of clause is not complete yet.

\section{RESEARCH METHODS}

This is a descriptive qualitative research which observed the phenomenon of swearing found in novel entitles Black Boy by Richard Wright. The data of this research is swearing found in Richard Wright's Black Boy as the main source of data. The method of collecting data used is observation and teknik lanjut catat. The data found are recorded then are given codes. The coding system is data number/title of novel/chapter/page/data such as 001/BB/017/damn thing. The writer used all the data so there was no data reduction. This research is used theory triangulation.

\section{DISCUSSION}

a. Type of Swearing Used on Richard Wright's Black Boy

Based on the analysis, the types of swearing words used on Richard Wright's Black Boy are;

\section{Religion Terms}


Swearing expression dealing with religion terms covers the euphemism of God's names such as God's name, evil, angel, hell, and heaven.

\begin{tabular}{|l|l|l|}
\hline No & Religion Terms & Amounts \\
\hline 1 & $\begin{array}{l}\text { God's name such as God's sake, God's } \\
\text { face, Goddamn/Goddamnit, Christ, } \\
\text { Lord, Holy }\end{array}$ & 24 \\
\hline 2 & Evil/Devil & 6 \\
\hline 2 & Angel & 1 \\
\hline 3 & Hell & 22 \\
\hline 4 & Damn & 11 \\
\hline
\end{tabular}

Tabel 1. Swearing Expression with Religion Terms

God's name euphemism consists of the use of God's name for swearing. These swearing are used mostly when the speaker felt angry. The examples of these swearing such as found in the following data;

a. "What's the matter, for the God's sake?" My mother asked for me, of Granny, of my brother, turning her face from one to anther (005/BB/II/50/God's sake)

b. "I have nothing to do with whether you go to school or not, she said. "You left the church and dead to me, dead to Christ.(037/BB/V/154/Christ)

c. Mrs. Moss came down in her robe.

"Mama, look what Richards was gonna do." Bess said, showing the can.

"He was gonna eat this in his room."

"Lord, boys, "Mrs. Moss said. You don't have to do that (096/BB/236/Lord)

d. "Holy cats", he said. He looked at us.

"Did you really find this here?"

"oh, yes sir," we said. (098/BB/XI/242/Holy)

Swearing dealing with religion terms that was firstly found is the use of evil and devil. Both refer to something unpleasant. However, there is also the use of angel as the swearing expression. The examples of these data are:

a. "You're an evil. You bring nothing but trouble. (035/BB/IV/148/evil)

b. "Then why write it?" she asked.

"Because people might want to read it."

"That's the Devil's work," she said and left. (057/BB/VII/185/Devil

c. "Them bastard brats of yours ain't no angel!" the landlady said. (012/B/II/angel)

Meanwhile, religion terms for swearing can be seen in the use of hell to swear such as in the following data: 
a. 'Hell, I ain't gonna stand near you, nigger! (018/BB/III/89/hell)

b. "That ain't gonna do you no good.

"Hell, they'll catch you. Rejection of naïve rebellion. (023/BB/III/90/hell)

2. Animal and Plant Terms

Tabel 2. Swearing Expression with Animal and Plant Terms

\begin{tabular}{|c|c|c|}
\hline No. & Animal Terms & Amount \\
\hline 1 & Bitch & 2 \\
\hline 2 & Pig & 1 \\
\hline 3 & Dog & 3 \\
\hline 4 & Hog & 1 \\
\hline 5 & Ass & 1 \\
\hline 6 & Rooster & 1 \\
\hline 7 & Monkey & 1 \\
\hline
\end{tabular}

Names of animals and plants can be used to swear too. However not all animals and plants can be used as swearing. The use is various among the culture. Some of the swearing found in Richard Wright's Black Boy use animal and plant terms, such as;

a. Bitch and Dog

"That's right, you bitch, "the young man said (046/BB/VI/164/bitch)

"Well, walk, you black sonofabitch" (069/BB/IX/black sonofabitch)

Bitch is female dog, wolf, or fox. This swearing sometimes appears in another form such as sonofabitch. In informal use, bitch means unpleasant woman. Bitch and dog are used for swearing to compare the traits of the swearing addressee with those of the animals.

b. Pig and $\mathrm{Hog}$

"Calling the hogs"

"Go home, pig!” (030/BB/III/92/hogs, pig)

Hog is a male pig with its sexual organ removed that is allowed to grow large so it can be eaten its meat. Hog and pig usually symbolize greediness so in informal use pig and hog means greedy persons. 
c. Ass

"Listen, nigger," he said to me, my ass is tough and a quarter is scarce. (101/BB/XII/250/Ass)

The next animal used for swearing is ass. Ass is the same as donkey. It is a mammal of the horse family which is usually smaller than a horse and has longer ears. In British informal, ass means foolish or stupid person.

d. Rooster

"I don't want to fight for white men. I'm no dog or rooster" (106/BB/XII/2623/Rooster)

Rooster is a male chicken. It is also known as cock. In slang terms both rooster and cock has another meaning. Rooster and cook can mean male genital. Rooster can also mean male homosexual.

e. Monkey "Yeeeessss, siiir," Shorty sang : but first he picked up his quarter and put it into his mouth.

“This monkey's got the peanuts," he chortled. (100/BB/XII/250/Monkey)

Monkey and other animals like cow, baboon, ape, skunk, polecat, and shrew, has been used in a metaphorical fashion for both a disreputable and unpleasant woman.

f. Nut

"Crush that nigger's nut, nigger!

"Hit that nigger!" (109/BB/XII/265/nut)

Nut means a hard-shelled dry fruit or seed with a separable rind or shell and interior kernel (http://www.merriam-webster.com/dictionary/nut). In slang language, nut means a person's head and in a vulgar use, it can mean testis. In addition, nut can also mean a person with silly and stupid behavior.

\section{Racism Terms}

\begin{tabular}{|l|l|l|}
\hline No & Racism Terms & Amount \\
\hline 1 & Black & 10 \\
\hline
\end{tabular}




\begin{tabular}{|l|l|l|}
\hline 2 & Negroes & 1 \\
\hline 3 & Nigger & 33 \\
\hline 4 & Coloured man & 1 \\
\hline 5 & White ( white people, white man & 7 \\
\hline
\end{tabular}

Tabel 3. Swearing Expression with Racism Terms

Black Boy is a novel with Afro American family background in America. There was still many discriminations found in the story. There are some swearing words dealing with racism terms such as negro, nigger, black, colored man, white folk, white, white man. These swearing words have something to do with skin color. Negro comes from Spanish and Portuguese words meaning black. The next words have the same meaning as negro is nigger and black. The following are the examples of those swearing:

a. "Maybe that's wrong with Negroes," I said. They take too much time. (078/BB/IX/205/Negroes)

b. "Crush that nigger's nut, nigger!

"Hit that nigger!" (109/BB/XII/265/nut)

c. Pack up your rags, you black bastard, and get", the landlady ordered. (015/BB/II/74/black bastard)

Besides, there is some swearing having something to do with white skin, such as white, white man, white people like the following ones:

a. ".... But I didn't want to sell Betsy to white people" "Why?"

"Because they're white," I said (017/BB/II/81/white)

b. "They say a white man bit a colored man up north and that colored man bit that white man, knocked him cold, and nobody did a damn thing! Urgent wish to believe in fight" (026/BB/III/white man, colored man)

\section{Stupidity Synonymy}

\begin{tabular}{|l|l|l|}
\hline No & Stupidity synonymy & Amount \\
\hline 1 & $\begin{array}{l}\text { Fool (fool, foolish, } \\
\text { foolishness) }\end{array}$ & 14 \\
\hline 2 & Silly & 1 \\
\hline 3 & Lousy & 1 \\
\hline
\end{tabular}


Tabel 4. Swearing Expression with Stupidity Synonym

There is swearing having synonymy with stupidity that is found in this novel for example fool (fool, foolish, foolishness), silly and lousy. The most used is fool. All kinds of the swearing is used for showing someone's stupidity. The following are the examples of swearing dealing with stupidity:

a. "Come on here, you little filthy fool," my mother called (007/BB/II/51/fool)

b. "Couldn't Granny find out who her father was?"

"For what, silly?"

"So she could know" (009/BB/II/57/silly)

c. "That goddamn lousy bastard sonofabitching bucket! I spoke in a whisper of hate and despair. (033/BB/III/107/lousy)

\section{Occupation}

\begin{tabular}{|l|l|l|}
\hline No & Occupation & Amount \\
\hline 1 & Whore & 1 \\
\hline 2 & Prostitute & 2 \\
\hline
\end{tabular}

Tabel 5. Swearing Expression with Occupation

Sometimes people swear by using word dealing with occupation. In Indonesian there is a swearing taken from the occupation name, bajingan which is actually is a name of the person whose job is driving a carriage. This phenomenon can be found in the novel such as whore and prostitute. Both are addressed to women engaging in sexual activity for getting money. The examples of the use of this swearing are:

a. "And what kind of whore is you?" The landlady shouted. (014/BB/II/74/whore)

b. You're just a common prostitute," Aunt Maggie pitched (013/BB/II/74/prostitute)

6. Sexual Activity

\begin{tabular}{|l|l|l|}
\hline No & Sexual Activity & Amount \\
\hline 1 & $(\mathrm{f} * * * * \mathrm{~g})$ & 2 \\
\hline
\end{tabular}

Tabel 6. Swearing Expression with Sexual Activity

There are only two swearing dealing with sexual activity found in this novel such

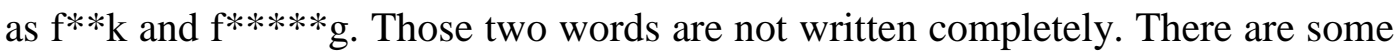


letters blanked to hide the real words because this swearing is considered as the worst swearing. This swearing has something to do with sexual activity. The example of the swearing with sexual activity term is;

a. 'Didn't you call him, Pease? If you say you didn't, I'll rip your gut string loose with this f- - k- i- g bar, you black granny dodger! You can't call a white man a liar and get away with it" (084/BB/IX/209/f- - k - i - g)

b. "Suck 'im in his f- - k - - g piece!" (109/BB/XII/265/ f- - k - - g)

7. Parts of Body

\begin{tabular}{|l|l|l|}
\hline No & Parts of Body & Amount \\
\hline 1 & Ass & 1 \\
\hline 2 & Piece & 1 \\
\hline
\end{tabular}

Tabel 7. Swearing Expression with Parts of Body

Parts of body are also used in swearing. This research found two swearing using part of body in this novel, namely ass and piece.

a. Ass

Ass is derived from the word arse which means a person's buttocks. This swearing is usually used to show someone who is stupid and irritating.

"Listen, nigger," he said to me, my ass is tough and a quarter is scare. (101/BB/XII/250/ass)

b. Piece

Piece, in this case means male genital.

“Suck 'im in his f- - k - - g piece!” (109/BB/XII/265/ f- - k - - g)

8. Family Terms

\begin{tabular}{|l|l|l|}
\hline No & Family Terms & Amount \\
\hline 1 & Bastard & \\
\hline 2 & Sonofabitch & \\
\hline
\end{tabular}

Tabel 8. Swearing Expression with Family Terms

The swearing has something to do with family terms found in this novel is bastard and sonofabitch. 


\section{a. Bastard}

Bastard is used to call a child born with no married parents or an illegitimate child. There are many swearing using the word bastard, one of them is;

"Pack up your rag, you black bastard, and get", the landlady ordered. (015/BB/II/74/Bastard)

b. Sonofabitch

Bitch is a female dog. This swearing is sometimes combined with the word son (the male child in the family). The following is the example of it;

"That goddamn lousy bastard sonofabitching bucket! I spoke in a whisper of hate and despair. (033/BB/III/107/sonofbiching)

\section{b. Linguistic Forms}

The most dominant linguistic forms used in swearing found in Richard Wright's Black

Boy are words and phrases. There is also a swearing in the form of sentence.

\section{Word}

The swearing expression in word forms that are found in Richard Wright's Black Boys consists of noun, adjective, and verb.

\begin{tabular}{|l|l|l|}
\hline No & Parts of Speech & Swearing Words \\
\hline 1. & Noun & $\begin{array}{l}\text { Nigger, Negro, hell, whore, } \\
\text { prostitute, pig, hog, dog, bitch, } \\
\text { rooster, cock, monkey, angel, } \\
\text { Christ, Lord, God, Evil, Devil, } \\
\text { foolishness. }\end{array}$ \\
\hline 2. & Verb & Damn \\
\hline 3. & Adjective & Black, silly, fool, Holy, bastard \\
\hline
\end{tabular}

Tabel 9. Swearing Words

a. Noun

Noun is the word identifying person, thing, place, animal, and idea. Swearing words used in the novel can be classified into;

1. Person such as nigger and Negro. Nigger is name for black people. Sometimes it is called Negro. The examples for noun referring to person are;

a) "Nigger, you mind's in a ditch," Amusingly moralistic. (019/BB/III/89/nigger) 
b) "Get down, nigger and put up your hands!" they order

2. Place such as hell. Hell is a place for punishing and tormenting in the afterlife. The used of this term can be found in the following examples:

a) "Hell, I woulda just killed her if she hada said that to me. (021/BB/III/90/hell)

b) “Hell, I ain't gonna stand near you, nigger (018/BB/III/89/hell,nigger)

3. Animal such as ass, rooster, cock, pig, hog, dog, bitch and monkey. Rooster and cock both refer to an adult male. Rooster and cock are used for referring male genital. Hog and pig are similar. Hog is male pig that its sexual organs have been removed and a hog is usually kept for its meat. Dog and bitch both refer to an animal with four legs that are usually kept by human for pet, hunting or guarding. Bitch refers to female dog. These animals are used for referring people who is unpleasant. The used of these swearing words such as;

a) “That's right, you bitch,"the young man said (046/BB/VI/164/bitch)

b) "Go home, pig!" (030/BB/III/92/hogs, pig)

c) "I don't want to fight for white men. I'm no dog or rooster" (106/BB/XII/262-3/Rooster)

4. Idea such as foolishness. Foolishness is used to show someone else stupidity. The use of it can be seen in the following example;

a) Quit talking foolishness! (008/BB/II/55/foolishness)

b. Verb

There is only one verb found in the novel. It is damn. It, however, has variation in the past form such as damned. This verb usually combined with the word God such as Goddamn and Goddamnit. The used of it can be found in the following examples;

a) "Now I'll be damned if I'm going to be beaten because of your hurt feeling. (053/BB/VI/174/damned)

b) It is my house and I'll have in it what I damn please," the landlady said.

c. Adjective

Swearing in adjective forms found in the novel are black, fool, and foolish. Those swearing function to modify noun such as the following data;

a) "You're foolish, "my mother said. (017/BB/II/foolish) 
b) "Aw, you're fool, "he said. Then he smiled quickly...(106/BB/XII/fool)

c) "Dick, look, you're so black, black, black, see? (076/BB/IX/203/black)

\section{Phrase}

The next linguistic unit used in swearing expression is phrase. Phrase is a group of words with headword and modifier. There are two kinds of phrases used as swearing in this novel. They are noun phrase and adjective phrase.

\section{a. Noun Phrase}

Noun phrase is a phrase with noun as its headword. The modifier can be noun, adjective, article, numeral, etc. Swearing in the form of noun phrase found in this novel is classified into three based on the position of the swearing. They are swearing as Headword, swearing as Modifier, and swearing as both Headword and Modifier.

1) Swearing as headword.

In this part, swearing words function as the headword of the phrase. The followings are some phrases in which the headword is swearing:

a. "You're just a common PROSTITUTE", aunt Maggie pitched. (013/BB/II/74/common prostitute)

b. "You little FOOL! Put that suitcase down!" (038/BB/V/159/little fool)

c. "You're a lucky BASTRD, cause if you'd said that to some other white man, you might've been a dead NIGGER now". (070/BB/IX/200/lucky BASTARD, a dead NIGGER)

The swearing words (in bold capital letters) on the sentences above all are nouns and functioning as headwords in the noun phrase.

2) Swearing as modifier.

In this part, swearing words function as modifier to the headword of the phrase. The followings are the examples of swearing as modifier found in the novel;

a. "Kill that DAMN thing!," my father exploded (001/BB/I/17/DAMN thing)

b. "You stop that, you EVIL gal", she shouted. (002/BB/I/47/EVIL gal)

c. "Who on earth put such sides into your NIGGER head?" (043/BB/VI/162/NIGGER head)

All the swearing words (in bold capital letters) are functioning as modifiers. They modify the headwords in the noun phrase. 
3) Swearing as headword and modifier.

In this part, swearing functions both as headword and modifier in the noun phrase. The followings are data concerning with swearing as headword and modifier;

a. "Pack your rugs, you black BASTARD and get," the landlady ordered (015/BB/II/74/black bastard)

b. "Say, what in hell are you glaring at me, you nigger BASTARD?" he demanded (047/BB/VI/164/nigger bastard)

c. "Well, walk, you black SONOFABITCH! (069/BB/IX/200/black SONOFABITCH)

The noun phrases above consist of swearing both as headword and modifier. The headwords are bold typed and the modifiers are italic.

\section{b. Adjective Phrase}

This kind of phrase has adjective as its headword. The modifier for this phrase is usually adverb. The followings are the adjective phrases found in this novel;

a. "What so damn FUNNY about that?" She asked (040/BB/V/160/damn funny)

b. "Sometimes I get so goddamn MAD I want to kill everybody," he spat I a rage.

"I like to sleep too goddamn MUCH. I'll die here. Or maybe they'll kill me" (111/BB/XIII/281/ goddamn mad, goddamn much)

The above phrases have adjectives (in capital letters) as their headwords and adverbs (in bold type) as modifiers. The swearing words on the sentences are functioning as modifiers.

\section{Sentences}

The biggest linguistic unit in swearing found in this novel is sentence. The followings are the sentences with swearing:

a. "Ha ha ha....Yeah, goddamnit they'll catch you (024/BB/III/90/godamnit)

b. "Goddamn. I thought. It happened quicker than I had expected. (049/BB/VI/170/Goddamn).

The two swearing expressions found in the novel are in the form of sentence but they are written with no spaces. They should be God damn and God damn it. 


\section{CONCLUSIONS}

Swearing is an application of language function namely expressive or emotive function. Swearing is used as an expression of feeling and emotion. Based on the research about swearing found in Richard Wright's Black Boy, we can say that the swearing types used in the novel are various. There are eight types of swearing used in it such as swearing with religion terms and God names, animal and plant terms, racial terms, stupidity terms, occupation terms, sexual terms, parts of body, and family terms. In addition, the swearing used on the novel also comes in the form of words, phrase, and sentences. No swearing found in the form of clause. Kinds of words used for swearing expression are; verb, adjective, and noun referring to people, things, places, animals, occupations, and idea. There are only two kinds of phrases used in swearing found in the novel such as noun phrase and adjective phrase.

\section{REFERENCES}

Arronof, M \&Fudeman, K (2005). What is Morphology. Oxford: Blackwell Publishing Ltd.

Budiwanto, C.. (2006). An Analysis of Swear Words in Jackass The Movie. Skripsi Fakultas Sastra Universitas Kristen Petra Surabaya.

Choiron. (2011). Manfaat Memaki (Bukan Kamus Makian). Kompasiana. Retrieved March 06, 2012 from http://bahasa.kompasiana.com/2011/03/26/manfaat-memaki-bukankamus-makian/

Crystal, D. (2003). The Cambridge Encyclopedia of Language. New York : The University of Cambridge

Geoffrey, H. (1998). Swearing: A social History of Foul Language, Oaths and Profanity in English. England: Penguin Book Blackwell

Laksana, I.K.D (2009). Tabu Bahasa: Salah Satu Cara Memahami Kebudayaan Bali. Denpasar: Udayana University Press 
Matthews, P. (1997). The Concise Oxford Dictionar of Linguistics. New York: Oxford University Perss Inc

Mey, J.L(1993). Pragmatics: An Introduction. Cambridge, Massachusettes: Blackwell Publisher.

Moloeng J.L (2008). Metodologi Penelitian Kualitatif Edisi Revisi. Bandung: PT.Remaja Rosdakarya

Ramlan, M. (2005). Ilmu Bahasa Indonesia: Sintaksis. Yogyakarta: CV Karyono.

Richards, J, Platt,J \& Weber,H (1985). Longman Dictionary of Applied Linguistics. Longman Group Limited: England.

Rosidi, A. (2011). Kata-kata Makian. Pikiran Rakyat. Retrieved March 06, 2012 from http://sainstory.wordpress.com/2011/12/01/kata-kata-makian

Wijana, I.D.P (2012). Makian Dalam Bahasa Indonesia: Studi Tentang Bentuk dan Referensinya dalam Jurnal Humaniora Fakultas Ilmu Budaya UGM

Wright, R. (1989). Black Boy: A Record of Childhood and Youth. New York: Harper \& Row Publisher 
